\title{
GOVERNMENTAL NONDISCLOSURE IN JUDICIAL PROCEEDINGS
}

\author{
MTLTON M. CARROW $\dagger$
}

\begin{abstract}
Due process requires that the right of the government to withhold information in administrative and judicial proceedings be subjected to "reasonable" limitations. This Article explores the extent of these limitations in terms of the kinds of individual interests affected and the type of information which is songht to be withheld. Mr. Carrow, as one who has written widely in the field of administrative law, suggests that the present basis for determining the limits of governmental nondisclosure, which rests upon a hierarchy of interests, be abandoned in favor of one which, by defining the kinds of information which are presumptively privileged, would leave the adjustment of interrelated interests to the court.
\end{abstract}

Government agencies collect, evaluate and store vast amounts of information pertinent to their functions and often of vital importance to others. Efforts to gain access to desired portions of such information by the legislature, members of the public or for use in judicial proceedings are sometimes resisted by the agencies and thus raise vexing political and legal problems. The arguments in favor of wider access to public information by the public and by private interests have recently been stated and documented under the banner of the "People's Right To Know." 1 The Congress has also been stirred to conduct an intensive investigation into the subject in the wake of refusals by executive departments to make available requested information to legislative investigating committees. ${ }^{2}$

$\dagger$ Member of the New York Bar; A.B., 1933, Syracuse University; LL.B., 1937, Harvard Law School; Subcommittee Chairman, Code of Federal Administrative Procedure, Committee on Hoover Commission Report on Legal Services and Procedure, New York County Lawyers Association; former Co-Chairman, Subcommittee on Iegal Services and Procedure, Committee on Administrative Law, Association of the Bar of the City of New York.

1. Cross, The People's Right To Know (1953); Parks, The Open Government Principle: Applying the Right To Know Under the Constitution, 26 GEo. WASH. I. REv. 1 (1957). Written for the American Society of Newspaper Editors, Cross's book describes and analyzes the areas in which the government withholds information from the public.

2. Beginning in November 1955, the House Committee on Government Operations, through its Government Information Subcommittee (Rep. John E. Moss, Chairman), conducted public hearings during 1955, 1956 and 1957 on Availability Of Information From Federal Departments and Agencies. See Second Report by the Committee on Government Operations, H.R. REP. No. 157, 85th Cong., 1st Sess. (1957). In its Twenty-Fifth Internediate Report, H.R. REP. No. 2947, 84th Cong., 2d Sess. 81 (1956) (hereinafter cited as H.R. Rep. No. 2947, 84th Cong., 2d Sess. (1956)) the Committee stated as follows: "Slowly, almost imperceptibly, a paper curtain has descended over the Federal Government. Behind this curtain lies an attitude novel 
Less attention has been given to the problem as it appears in its most acute aspect, namely, when an administrative agency, in the course of an adjudicative proceeding, conducted either before the agency or the courts, utilizes information in its possession to the detriment of a person, but at the same time asserts a right, or privilege, to withhold such information from the affected person, as well as from the adjudicative tribunal.

This situation has confronted the courts in a number of different instances in recent years. Cases have arisen where agencies, on the basis of undisclosed information, have discharged people from public employment, ${ }^{3}$ caused their discharge from private employment in companies performing work under military contracts, ${ }^{4}$ denied applications of United States citizens for passports, ${ }^{5}$ excluded a former resident alien from readmission to the United States as well as aliens applying for the first time, ${ }^{6}$ rejected an application for the suspension of deportation where the record warranted favorable action, ${ }^{7}$ refused access to an accident investigation report in a suit against the Government under the Federal Tort Claims Act, ${ }^{8}$ required registration of an

to democratic government-an attitude which says that we, the officials, not you, the people, will determine how much you are to be told about your own government."

On May 17, 1954, President Eisenhower sent a letter to the Secretary of Defense in connection with testimony at the Army-McCarthy hearings before the Senate's Permanent Subcommittee on Investigations, directing him to instruct the employees of his department "that in all of their appearances before the subcommittee of the Senate Committee on Government Operations regarding the inquiry now before it, they are not to testify to any such conversations or communications or to produce any such documents or reproductions." N.Y. Times, May 18, 1954, p. 24, col. 1. A memorandum from Attorney General Brownell accompanied this letter documenting all the instances from President Washington's administration through that of President Truman's where the Executive had refused to divulge information in his possession to the Congress. Ibid.

On January 22, 1958, President Eisenhower wrote a letter to Senator Lyndon P. Johnson, Chairman of the Senate Preparedness Subcommittee, in which he refused to comply with a request to furnish to the subcommittee "the so-called Killian and Gaither panel reports," which had been prepared at the President's request for the purpose of assessing the nation's military status. After noting that "we must be careful to maintain the proper separation of powers between the Executive and Legislative branches of the Government," he said: "I consider it improper and unwise for me to violate the confidence of the advisory relationship that has existed between me and these panels or to make public the highly secret facts contained in their reports." N.Y. Times, Jan. 23, 1958, p. 10, col. 3.

3. Bailey v. Richardson, 182 F.2d 46 (D.C. Cir. 1950), aff'd by an equally divided Court, 341 U.S. 918 (1951).

4. Greene v. McElroy, 254 F.2d 944 (D.C. Cir. 1958), cert. granted, 27 U.S.L. WEEK 3134 (U.S. Oct. 27, 1958) (No. 180).

5. Briehl v. Dulles, 248 F.2d 561 (D.C. Cir. 1957) ; Dayton v. Dulles, 254 F.2d 71 (D.C. Cir. 1957). Both of these cases were reversed by the Supreme Court, Kent v. Dulles, 357 U.S. 116 (1958), Dayton v. Dulles, 357 U.S. 144 (1958), without reaching the question of the right of the Government to withhold information.

6. Shaughnessy v. United States ex rel. Mezei, 345 U.S. 206 (1953); United States ex rel. Knauff v. Shaughnessy, 338 U.S. 537 (1950).

7. Jay v. Boyd, 351 U.S. 345 (1956).

8. United States v. Reynolds, 345 U.S. 1 (1953). 
organization under the Subversive Activities Control Act, ${ }^{9}$ and instituted criminal prosecutions. ${ }^{10}$

Except for the criminal prosecutions and the registration case, the courts have upheld the right of agencies to withhold pertinent information. In practically all of these cases, however, the benches were closely divided and strong dissenting opinions were filed.

The difficulties arise from the effort to adjust the competing interests of the individual, on the one hand, to obtain full disclosure of information needed by him to present or meet the issues arising in the adjudicative proceeding, and, on the other, the interest of government officials in something less than full disclosure when they believe disclosure would interfere with effective administration or, in their opinion, would otherwise be contrary to the public interest. Underlying these immediate interests are at least two fundamental considerations. From the standpoint of the government, and in the public interest, there is a need at present to prevent disclosure of information affecting the security of the nation. And from the standpoint of the individual, and also in the public interest, there is the responsibility of the government to see that justice is done, which, as applied here, means the enforcement of procedural due process.

In seeking standards by which to determine the conflicts that occur from the interaction of these interests, the courts, and the legislatures, have approached the problem from two different directions. They seek, first, to determine whether the nature of the individual's interest that is affected by a refusal to disclose information has any bearing on the right of the government to withhold information, or, in its more general aspects, whether standards of procedural due process vary according to the nature of the individual interest that is affected. And second, they seek to correlate the right of nondisclosure with the type of information that is sought to be withheld.

Since these are not mutually exclusive factors they often appear together in the cases. But for purposes of analysis, this Article will deal with them separately. The inquiry, however, must first be placed in an appropriate constitutional context and this calls for an examination of the legal basis for nondisclosure. ${ }^{11}$

9. Communist Party v. Subversive Activities Control Bd, 254 F.2d 314 (D.C. Cir. 1958).

10. Jencks v. United States, 353 U.S. 657 (1957) ; Roviaro v. United States, 353 U.S. 53 (1957) ; State v. Hunt, 25 N.J. 514, 138 A.2d 1 (1958).

11. The standard texts on the subject are McCoRMICK, EvIDENCE 302-13 (1954) and 8 WIGMORE, EVIDENCE $\$ \S 2367-79$ (3d ed. 1940). A recent article dealing with most of the procedural aspects of the problem is Timbers \& Cohen, Demands of Litigants for Government Information, 18 U. PITT. L. REv. 687 (1957). A perceptive brief discussion of the subject is Walkley, The $U_{\text {se }}$ of Undisclosed Evidence $b_{y}$ 


\section{The Legar Basis for Nondisclosure}

"[T]here appears to be no principle of testimonial privilege or basic consideration of policy exempting any officer or agent of the state from the duty to give such testimony as may be required in a duly held judicial investigation," said Judge Fuld for the New York Court of Appeals in 1953.12 This reflects a basic tenet of the law of evidence. ${ }^{13}$

Such requirement of disclosure is, in criminal cases, identified with the constitutional right under the sixth amendment of a defendant "to be informed of the nature and cause of the accusation" and "to be confronted with the witness against him;" and, as to both criminal and civil cases, the due process clauses of both the fifth and fourteenth amendments are safeguards against unfair procedural practices.

However, the common law of evidence has long recognized certain "rules of privilege" which authorize the withholding of pertinent facts in a judicial proceeding, and these common-law rules presumably are read into the Constitution. Said Professor McCormick:

"They do not in any wise aid the ascertainment of truth, but rather they shut out the light. Their sole warrant is the protection of interests and relationships which, rightly or wrongly, are regarded as of sufficient social importance to justify some incidental sacrifice of sources of facts needed in the administration of justice." 14

Such privilege applies to marital communications, communications between client and lawyer, information secured in the course of the physician-patient relationship, confessions, self-incriminating statements and evidence illegally obtained. ${ }^{15}$ In addition, a similar evidential privilege is said to apply to "governmental secrets." 16

But a distinction should be made between the governmental privilege and an individual's privileged communications. The latter obvi-

Government Officials in Administrative and Judicial Proceedings, 45 CALIF. L. REv. 524 (1957). See also AlLEN, LAw AND ORDERS 369-85 (2d ed. 1956) (the problem in England); and PUBLIC LAW PROBLEMS IN INDIA (Ebb ed. 1957), a survey report which finds that this problem both in the United States and India is one that requires further research. For a discusion of the problem as it relates to the legislature, see Bishop, The Executive Right of Privacy: An Unresolved Constitutional Question, 66 YALE L.J. 477 (1957).

12. City of Buffalo v. Hanna Furnace Corp., 305 N.Y. 369, 373, 113 N.E.2d 520, $522(1953)$.

13. "For more than three centuries it has now been recognized as a fundamental maxim that the public (in the words sanctioned by Lord Hardwicke) has a right to every man's evidence." 8 WIGMORE, op. cit. supra note $11, \S 2192$.

14. McCormick, op. cit. supra note 11 , at 152 .

15. Id. at 168 .

16. Id. at 302; 8 WIGMORE, op. cit. supra note $11, \S \S 2367-79$. 
ously protect private "interests and relationships" and those who claim them have no legal obligation other than the protection of their own interests. The government, on the other hand, particularly where it is engaged in adjudicative proceedings, not only may have an interest in withholding information but it also is subject to the constitutional requirement that its adjudicative proceedings meet procedural due process standards. In other words, it has the duty of seeing that justice is done. ${ }^{17}$

Since the common-law evidential privilege of the government may thus be offset by a duty to provide fair procedure, can an agency's claim of a right to withhold information be reconciled with the requirement of procedural due process?

It is not, in fact, easily reconciled. The best that so far has been said in support of nondisclosure is that "reasonable" limitations can and have been imposed on both substantive and procedural rights of due process. ${ }^{18}$ If this criterion is accepted, the problem in this area is to break down and define what are reasonable limitations.

This is true even where the agency's claim of a right to avoid disclosure is made to rest upon grounds other than the government's evidentiary privilege. It has been urged occasionally that the executive agencies have, by virtue of the separation of powers doctrine, an inherent right to withhold information under an "executive privilege." 19

17. In Communist Party v. Subversive Activities Control Bd., 254 F.2d 314 (D.C. Cir. 1958), which required disclosure in a civil adjudicative proceeding of prior reports made by a Government witness, Judge Prettyman, for the court, pointed out that "the opinion of the Supreme Court in the Jencks case [which required such disclosure in a criminal prosecution] . . is based upon the elementary proposition that the interest of the United States is that justice be done. The same elementary proposition applies here and leads to the same result."

18. See Dayton v. Dulles, 254 F.2d 944 (D.C. Cir. 1957), rev'd on other grounds, 357 U.S. 144 (1958), where Judge Prettyman said: "A regulation of a liberty, reasonable in relation to its subject and adopted in the interest of the community, is due process." But see Mr. Justice Jackson, dissenting in Shaughnessy v. United States ex rel. Mezei, 345 U.S. 206, 224 (upholding an exclusion order based on confidential information): "Procedural due process is more elemental and less flexible than substantive due process . . . Only the untaught layman or the charlatan lawyer can answer that procedures matter not. Procedural fairness and regularity are of the indispensable essence of liberty. Severe substantive laws can be endured if they are fairly and impartially applied. Indeed, if put to the choice, one might well prefer to live under Soviet substantive law applied in good faith by our common-law procedures than under our substantive law enforced by Soviet procedural practices. Let it not be overlooked that due process of law is not for the sole benefit of an accused. It is the best insurance for the Government itself against those blunders which leave lasting stains on a system of justice but which are bound to occur on ex parte consideration."

19. See Bishop, The Executive's Right of Privacy: An Unresolved Constitutional Question, 66 YALE L.J. 477 (1957). This "executive privilege" theory has antecedents in the English doctrine that the King is immune from judicial process, both as to the requirement of attendance and of divulging information. See Street, State Secrets- $A$ Comparative Study, 14 MODERN L. REv. 121 (1951).

When the question arose in the treason trial of Aaron Burr, Chief Justice Marshall, sitting as a trial judge, indicated that he did not believe such immunity applied to the President because the nature of his office was different from that of the King. 
In many more instances, the provisions of certain general statutes have been invoked as authorizing, expressly or impliedly, an agency right of nondisclosure. ${ }^{20}$ Thus, in United States ex. rel. Touhy v. Ragen ${ }^{21}$ and Boske v. Comingore ${ }^{22}$ regulations restricting access to agency

United States v. Burr, 25 Fed. Cas. 30, 34 (No. 14) (C.C. Va. 1807). See also Corwin, The President, Office and Powers 112-13 (4th rev. ed. 1957). Marshall granted Burr's motion for the issuance of a subpoena directing the President to appear and testify with respect to certain letters and documents in his possession, but President Jefferson refused to attend, although he offered to have his deposition taken in Washington. This offer, apparently, was never acted upon, and the subpoena was not enforced. The requested documents were eventually produced by the Government's attorney.

No court, however, has ever compelled the chief executive to furnish information in a judicial proceeding. There appear to be but two decisions on the subject, one by the highest court of New Jersey and the other by that of Pennsylvania, both of which held that the separation of powers doctrine barred an order to compel a governor to disclose information in his possession. Thompson v. German Valley R.R., 22 N.J. Eq. 111 (Ch. 1871); Appeal of Hartranft, 85 Pa. 433 (1877).

These determinations support a claim of "executive privilege" on the part of the chief executive, and his right to withhold information at his discretion seems to be conceded. See H.R. REp. No. 2947, 84th Cong., 2d Sess. 86 (1956). Professor Wigmore takes the position, however, that the exemption applies only to the requirement of attendance at judicial proceedings, and does not apply to the furnishing of information. 8 WIGMORE, op. cit. sitpra note $11, \$ \$ 2369,2370$.

20. The various authorities relied on by the federal agencies have been analyzed and classified on the basis of replies to a questionnaire sent to all the agencies by the House of Representatives Special Subcommittee on Government Information, H.R. Rep. No. 2947, 84th Cong., 2d Sess., Ex. III, at 281 (1956).

21. 340 U.S. 462 (1951). This was a habeas corpus proceeding instituted by an inmate of a state penitentiary against the warden. A subpoena duces tecum was served on an FBI agent requiring production of certain records which, petitioner claimed, contained evidence establishing that his conviction was brought about by fraud. The agent appeared as a witness but declined to produce the records, citing a regulation of the Department of Justice which required him to refuse to produce the records on the instructions of the Attorney General. A contempt conviction by the district court was reversed, the Court, per Mr. Justice Reed, upholding the validity of the regulation insofar as it applied to subordinate officials, and citing Boske v. Comingore, 177 U.S. 459 (1899), as controlling.

22. 177 U.S. 459 (1899) (upholding Treasury Department regulation which prohibited collectors of internal revenue and their subordinates from providing certain reports). See also Appeal of SEC, 226 F.2d 501 (6th Cir. 1955) (contempt order against general counsel of SEC reversed where counsel refused to produce, in a stockholder's derivative action, official records on basis of SEC rule prohibiting disclosure by subordinate officials).

However, can the chief executive "cast the cloak of immunity" over his subordinates? The only case that seems to have dealt with it is Appeal of Hartranft, $85 \mathrm{~Pa}$. 433 (1877), where the Pennsylvania Supreme Court held that not only the Governor, but also those officials who carried out the Governor's orders to have the National Guard intervene in a strike, were exempt from judicial process. But, where no such specific directive is present, it is doubtful that a member of an executive department or an administrative agency can claim to be acting as the "alter ego" of the chief executive. See Timbers \& Cohen, Demands of Litigants for Government Information, 18 U. PITT. L. Rev. 687, 701 (1957).

Although such regulations have been upheld by the Supreme Court where demands for information were made upon subordinate agency officials, and where the agency was not a party to the litigation, they have not been specifically tested in a case against an agency head where it is unlikely that such a claim would be upheld. See Mr. Justice Frankfurter's concurring opinion in United States ex rel. Touhy $\mathrm{v}$ Ragen, 340 U.S. 462, 473 (1951). Furthermore, such a regulation is not applicable to a criminal prosecution. Jencks v. United States, 353 U.S. 657 (1957); United States v. Andolschek, 142 F.2d 503 (2d Cir. 1944). It is questionable that it would be effective in a civil case where the agency was a party litigant. See United States v. General 
information drafted upon general provisions of the "Housekeeping" Act of $1789^{23}$ were upheld. Although a recently enacted amendment to this legislation precludes its further use toward this end, ${ }^{24}$ the Administrative Procedure Act of 1946 contains language which appears to give considerable leeway to agencies to refuse disclosure. ${ }^{25}$ But the constitutional inquiry into procedural due process is not avoided by statutory enactment. Here also a balance must be struck on the basis of the nature of the interest affected and the type of information withheld.

\section{The Nature of the Interest Affected}

In dealing with a governmental claim of privilege to withhold information, the courts have made distinctions based on whether crim-

Motors Corp., 2 F.R.D. 528 (N.D. Ill. 1942), where it is indicated that the Attorney General's regulation applies only to litigation between private parties. This is criticized in Timbers \& Cohen, Demands of Litigants for Government Information, 18 U. PITT. L. REv. 687, 697 (1957). But see McCormIck, op. cit. supra note 11, at 305 .

23. Rev. Stat. \$161 (1875), 5 U.S.C. $\$ 22$ (1952). This now provides: "The head of each department is authorized to prescribe regulations, not inconsistent with law, for the government of his department, the conduct of its officers and clerks, the distribution and performance of its business, and the custody, use and preservation of the records, papers, and property appertaining to it."

24. Pub. L. No. 619, 85th Cong., 2d Sess. (Aug. 12, 1958), provides, "Section 161 of the Revised Statutes of the United States [5 U.S.C. \$ 122] is amended by adding the following new sentence: 'This section does not authorize withholding information from the public or limiting the availability of records to the public." "For a discussion of this see Mitchell, Government Secrecy in Theory and Practice: "Rules and Regulations" as an Autonomous Screen, 58 COLUM. L. REv. 199 (1958).

It should be noted that a federal statute imposes criminal penalties on government employees who disclose certain types of information made confidential by statute. 18 U.S.C. \$1906 (1952).

25. 60 Stat. 239 (1946), 5 U.S.C. $\$ 1002$ (1952). Apparently under the terms of the act an agency can withhold information respecting "any function of the United States requiring secrecy in the public interest" and "any matter relating solely to the internal management of an agency." Also it need not make available for public inspection final opinions and orders in the adjudication of cases which are "required for good cause to be held confidential." In addition, matters of official record may be withheld when they contain "information held confidential for good cause found."

The courts, however, have not specifically referred to these provisions as a basis for upholding a claim to withhold information on broader terms than those recognized by the common-law types of privileged information or those specifically protected by statute.

In the Code of Federal Administrative Procedure proposed by the American Bar Association Special Committee on Legal Services and Procedure to replace the Administrative Procedure Act, the various phrases of that act which authorize an agency to withhold information were eliminated, and the following provision was made for withholding information: "Exemptions. The provisions of this section shall not require disclosure of subject matter which is (1) specifically exempt from publication by statute, (2) required to be kept secret in the protection of the national security, (3) submitted in confidence pursuant to statute or agency rule or discretion, or (4) the disclosure of which would be a clearly unwarranted invasion of personal privacy. Nothing contained in this section shall be deemed to authorize the withholding of information except as specifically stated in this subsection." S. 4094, 85th Cong., 2d Sess. \$1002(f) (1958). 
inal or civil liabilities were at stake, and also whether the nature of the interest affected by an adverse agency determination, based on undisclosed information, was such as to require the full complement of procedural due process safeguards.

In the criminal cases, Judge Learned Hand's statement in United States $v$. Andolschek ${ }^{26}$ on this subject has become firmly rooted:

"So far as they directly touch the criminal dealings, the prosecution necessarily ends any confidential character the documents may possess; it must be conducted in the open, and will lay bare their subject matter. The government must choose; either it must leave the transactions in the obscurity from which a trial will draw them, or it must expose them fully."

This was recently applied in Jencks $v$. United States, ${ }^{27}$ where $\mathrm{Mr}$. Justice Brennan, for the Supreme Court, said that, even though the Government claimed a privilege to withhold certain reports of its witnesses based on its interest in safeguarding the privacy of its files, "we hold that the criminal action must be dismissed when the Government, on the ground of privilege, elects not to comply with an order to produce, for the accused's inspection and for admission in evidence, relevant statements or reports in its possession of government witnesses touching the subject matter of their testimony at the trial." 28 Other language in the opinion indicates that even if the claimed privilege involved information relating to "vital national interest," the same result would be

26. 142 F.2d 503, 506 (2d Cir. 1944).

27. 353 U.S. 657 (1957).

28. Id. at 672. See also State v. Hunt, 25 N.J. 514, 138 A.2d 1 (1958). In reversing a conviction for murder the court there said: "Since the county prosecutor's primary function is not to convict but to see that justice is done : . he, as well as the defense counsel, should readily welcome the wholesome principle which we now approve for the administration of justice in our State, that where it appears that a State's witness [a detective who accompanied the prisoner in transit] has made prior notes or statements relating to the subject matter of the direct testimony which he has given, the defense is entitled to inspect and use on cross-examination the prior notes or statements if they are or can be made available. And the principle is generally applicable without any preliminary showing of inconsistency . . . or any resulting right in the State to introduce the notes or statements or corroborative evidence on its behalf. ." Id. at 530-31, 138 A.2d at 10. But see United States v. Nugent, 346 U.S. 1 (1953). In a prosecution for refusal to submit to induction under the Selective Service Act, defendant, who had claimed exemption as a conscientious objector, is entitled to a "fair resume" of the FBI report upon which his military classification is based, but not the report itself. See Blalock v. United States, 247 F.2d 615 (4th Cir. 1957). Contra, United States v. Jacobson, 154 F. Supp. 103 (W.D. Wash. 1957).

It should be noted that in civil and administrative judicial proceedings, where the requested information is not privileged under the law of evidence or by statute, the Jencks rule is applicable. Communist Party of the United States v. Subversive Activities Control Bd., 254 F.2d 314 (D.C. Cir. 1958); NLRB v. Adhesive Products Corp., 258 F.2d 403 (2d Cir. 1958). 
reached in a criminal case, although a specific test of that issue has not yet arisen. ${ }^{29}$

Following the Jencks decision Congress enacted a statute which appears to modify Mr. Justice Brennan's language as to dismissal of a prosecution where relevant statements of Government witnesses are not produced. It provides:

"If the United States elects not to comply with an order of the court . . . to deliver to the defendant any such statement, or such portion thereof as the court may direct, the court shall strike from the record the testimony of that witness, and the trial shall proceed unless the court in its discretion shall determine that the interests of justice require that a mistrial be declared." 30

Although Jencks indicates the possibility that no privilege may be available in criminal prosecutions, this is not true in civil cases. "It is unquestionably true," said the Court, "that the protection of vital national interests may militate against public disclosure of documents in the Government's possession. This has been recognized in decisions of this Court in civil causes . . . ." ${ }^{1}$ This, apparently, refers to the secrets of state privilege. But there is little doubt that the other types of privileged information will also be recognized in civil cases.

However, in a number of instances in recent years, the courts have applied, in civil cases, not only the recognized evidentiary privileges of the Government, but a theory that certain kinds of individual interests affected by Government action are not entitled to as much procedural protection as other kinds of interests, and that agency determinations affecting such interests may be based upon undisclosed information, privileged or not. These lesser interests include, with approval by the United States Supreme Court, employment in the Government, ${ }^{32}$ admis-

29. "[I]n criminal causes," said Mr. Justice Brennan, ". . . the Government can invoke its evidentiary privileges only at the price of letting the defendant go free. The rationale of the criminal cases is that, since the Government which prosecutes an accused also has the duty to see that justice is done, it is unconscionable to allow it to undertake prosecution and then invoke its governmental privileges to deprive the accused of anything which might be material to his defense. . . " 353 U.S. at 671, quoting from Mr. Justice Vinson's opinion in United States v. Reynolds, 345 U.S. 1,12 (1953).

30. 18 U.S.C. $\$ 3500$ (d) (Supp. V, 1958).

31. 353 U.S. at 670 .

32. Bailey v. Richardson, 182 F.2d 46 (D.C. Cir. 1950), aff'd by an equally divided Court, 341 U.S. 918 (1951). In that case the Court upheld an agency's refusal to disclose the names of informants who were responsible for the discharge of a Government employee on disloyalty grounds. The court of appeals' opinion, which was sustained, avoided the due process issue by holding that a Government job is not a property right, the deprivation of which entitles one to a judicial type determination. In a strong dissent, Judge Edgerton insisted that the dismissal was punitive and therefore all procedural safeguards of a judicial proceeding were applicable, including 
sion of aliens to the United States, ${ }^{33}$ and applications for suspension of deportations. ${ }^{34}$ To these has now been added employment in private companies holding Defense Department contracts. ${ }^{35}$ In each of these instances confidential and undisclosed information was used by the agency as a basis for acting adversely to the individual. The justification was simply that such interests did not require the same degree of procedural protection as do other interests. ${ }^{36}$

the right to disclosure of the names of informants and the right to cross-examine them. The views of the dissenting Supreme Court Justices in the Bailey case, supporting the views of Judge Edgerton on this issue, were expressed in separate opinions in Joint Anti-Fascist Refugee Comm. v. McGrath, 341 U.S. 123 (1951).

33. Shaughnessy v. United States ex rel. Mezei, 345 U.S. 206 (1953); United States ex rel. Knauff v. Shaughnessy, 338 U.S. 537 (1950). In the Mezei case the excluded alien (his exclusion was based on undisclosed information) had formerly been a resident of the United States but had traveled abroad for a period of nineteen months. Because of this, Mr. Justice Clark, for the majority of the Court, ruled that he was in the same class as an entrant alien. The Supreme Court had previously ruled that a lawful resident alien "may not captiously be deprived of his constitutional rights to procedural due process. Kwong Hai Chew v. Colding, 344 U.S. 590 (1953)." 345 U.S. at 213. The dissenting Justices in Mezei were Mr. Justices Black, Douglas, Frankfurter and Jackson. In the Knauff case the Attorney General had excluded a woman, married to a naturalized American citizen, stationed in Germany, who sought admission under the War Brides Act. She was excluded on the basis of confidential information and without any hearing. Mr. Justices Frankfurter, Jackson and Black dissented and two Justices, Douglas and Clark, took no part. After this decision Congress passed a special act providing for Mrs. Knauff's admission to the United States.

34. Jay v. Boyd, 351 U.S. 345 (1956). The applicant was ordered deported on the basis of his membership in the Communist Party, such membership terminating more than ten years before the proceeding was instituted. He had been a resident of the United States for forty years, had a family and a record of exemplary conduct. The special inquiry officer, who was assigned to hear his application for suspension of deportation, found that, on the record, the applicant was entitled to favorable consideration, but recommended denial, on the basis of confidential information, in accordance with a regulation issued by the Attorney General. The case turned on the validity of such regulation. The majority of the Court held that in suspension of deportation cases the Attorney General had an "unfettered discretion" and was thus not required to disclose the information on which he acted. Vigorous dissents were filed by Mr. Chief Justice Warren and Mr. Justices Black, Frankfurter and Douglas.

35. Greene v. McElroy, 254 F.2d 944 (D.C. Cir. 1958), cert. granted, 27 U.S.L. WEER 3134 (U.S. Oct. 27, 1958) (No. 180). This was a declaratory judgment action by an officer-employee of a company engaged in work under a Defense Department contract, which challenged the revocation of his security clearance by the Secretary of the Navy. In the administrative adjudicative proceedings leading to the revocation order, the Government had refused to produce "confidential reports of the FBI and other investigative agencies" upon which the order was based. It appears that no claim was made that these reports contained privileged information. As a result of the Secretary's action the employee was dismissed from his $\$ 18,000$ per year job in which he had dealt with classified information, and was given a $\$ 4,400$ per year job, where he did not have access to such information.

36. In Greene v. McElroy, supra note 35, at 951, the court was troubled by the thought that the only relief it could grant would be the restoration of the employee to his position. This "would amount to ordering his restoration to access to classified information," said the court. But if there was a genuine issue of privilege in the case, the proper procedure would have been for the agency to file a formal claim of privilege and for the court to determine for itself that the information is privileged. If the information were held not to be of a privileged type, the court could order its production. Failure to produce might be enforced by contempt proceedings (although this admittedly raises unresolved issues) or, as the post-Jencks statute indicates, by a requirement that the information be eliminated as a basis of the agency action. Ultimately, the issue narrows down to the question whether it is 
All but the last case were decided by sharply divided Courts (Bailey 4-4, Mezei 4-3 and Jay 5-4) and the harshness of the results evoked stinging dissents. Do these decisions provide for "reasonable" limitations on procedural due process? Emphatically not, argue the dissenters. ${ }^{37}$ The Greene case, in particular, dealing with private employment, demonstrates the fact that once erosion of procedural safeguards gets under way in areas not believed to be important, it becomes difficult to prevent it from reaching into other areas of admittedly vital importance. Mr. Justice Jackson's statement that "procedural due process is more elemental and less flexible than substantive due process" 38 becomes increasingly significant.

\section{Types of Information That May Be Privileged}

As part of the common law of evidence certain kinds of information in the hands of governmental agencies have been deemed privileged. Such privilege is said to apply to "secrets of state", "informers" and "official information." 39

In the light of recent developments in this field, it may be helpful, for the purposes of this discussion, to break these down into several additional categories, as follows: (1) secrets of state, (2) identity of informers of violations of law, and in some instances, the contents of the information furnished by informers, (3) information obtained by investigation, and (4) communications relating to the internal management of agencies. In addition to these common-law subjects, there are the subjects which have been made privileged by statute, which we will identify as (5) information furnished an agency as required by statute.

the court or the agency which has the final authority to decide that information can be withheld. But in this case the court did not meet this issue because it found that the kind of interest affected was one not entitled to these procedural safeguards.

37. In Jay v. Boyd, 351 U.S. 345, 361 (1956), Mr. Chief Justice Warren said: "In conscience, I cannot agree with the opinion of the majority. It sacrifices to form too much of the American spirit of fair play in both our judicial and administrative processes." In the Mezei case, Mr. Justice Jackson said: "Our law may, and rightly does, place more restrictions on the alien than on the citizen. But basic fairness in hearing procedures does not vary with the status of the accused. If the procedures used to judge this alien are fair and just, no good reason can be given why they cannot be extended to simplify the condemnation of citizens. If they would be unfair to citizens, we cannot defend the fairness of them when applied to the more helpless and handicapped alien." Shaughnessy v. United States ex rel. Mezei, 345 U.S. 206, 225 (1953).

38. Id. at 224.

39. UNIFORM RULES OF EVIDENCE 33, 34, 36; 8 Wigmore, op. cit. supra note 11 , $\$ 2367$. See generally HANDBOOK OF THE NATIONAL CONFERENCE OF CoMmissioners ON UNIFORM STATE LAWS (1953). The Uniform Rules, insofar as governmental privilege is concerned, are practically the same as those in the MODEL CODE OF EvIDENCE rules $227,228,230$ (1942). 


\section{Secrets of State}

Information "involving the public security or concerning the military or naval organizations or plans of the United States, or a State or Territory, or concerning international relations" has been defined as "secrets of state." 40 Although there are not many cases in which the issue has arisen, it is generally agreed that an agency's claim of privilege to withhold such information will be upheld in civil adjudication before agencies and courts ${ }^{41}$ although possibly not in criminal cases. ${ }^{42}$

The obvious purpose of this privilege is to protect information in the possession of the Government which might be used to the nation's disadvantage by its actual or possible enemies. Since it deals with military affairs and international relations, there would be some constitutional basis for it, at least where the Chief Executive is concerned, as he is the Commander-in-Chief of the armed forces and has a nonreviewable discretion in the handling of foreign affairs. ${ }^{43}$

The only case in which the Supreme Court appears to have directly applied the privilege to withhold military information in derogation of individual interest is Totten $v$. United States. ${ }^{44}$ There, the Court upheld the dismissal of an action brought by the administrator of the estate of one Lloyd for payment of a salary under an alleged agreement made between President Lincoln and Lloyd whereby Lloyd was to spy behind the Confederate lines during the Civil War and was to be paid two hundred dollars per month plus expenses. All he had received was reimbursement for expenses. Mr. Justice Field, for the Court, stated that compared to the husband-wife or attorney-client privilege "much greater reason exists for the application of the principle to cases of contract for secret services with the Government. " 45

40. Uniform Rules of Evidence 33; Model Code of Evidence rule 227 (1942).

41. Mr. Chief Justice Vinson, in United States v. Reynolds, 345 U.S. 1, 6-7 (1953), stated that the privilege against revealing military secrets is "a privilege which is well established in the law of evidence." Professor Wigmore who, according to the Chief Justice was one of "the most outspoken critics of governmental claim to privilege," called this a "genuine testimonial privilege." 8 WIGMORE, op. cit. supra note $11, \$ 2378$. See also MCCorMICK, op. cit. supra note 11 , at 302 .

42. See note 29 supra.

43. In Chicago \& So. Air Lines v. Waterman S.S. Corp., 333 U.S. 103, 111 (1948) (holding that a CAB order denying a certificate for an overseas air service, which was subject to approval by the President, could not be reviewed), MIr. Justice Jackson, for the Court, said: "The President, both as Commander-in-Chief and as the Nation's organ for foreign affairs, has available intelligence services whose reports are not and ought not to be published to the world It would be intolerable that courts, without the relevant information, should review and perhaps nullify actions of the Executive taken on information properly held secret."

44. 92 U.S. 105 (1875).

45. Id. at 107. "Both employer and the agent must have understood that the lips of the other were to be for ever sealed respecting the relation of either to the 
As the Uniform Rules of Evidence definition shows, secrets of state include information concerning international relations, as well as that relating to military security. Where such information is utilized by the President of the United States, it is clearly privileged. ${ }^{46}$ It has also been claimed by other officials. In Briehl v. Dulles, ${ }^{47}$ the Secretary of State had refused to renew a passport on the basis of secret information indicating that the applicant had communist affiliations. Judge Prettyman, for the Court of Appeals for the District of Columbia, stated that the foreign policy of the United States was based upon the proposition that the "Communist movement today is an international conspiracy aimed at world domination and a threat to the internal security of this country" 48 and also, that "foreign affairs and decisions on foreign policy are political matters entrusted by the Constitution to the political departments of the Government, and . . . the judiciary has no part in them." 49 In view of these things, the court held that the Secretary of State had a right to withhold information relating to applicant's alleged communist activities, and the right to refuse to renew the passport on the basis of such secret information. ${ }^{50}$

matter. This condition of the engagement was implied from the nature of the employment, and is implied in all secret employments of the government in time of war, or upon matters affecting our foreign relations, where a disclosure of the service might compromise or embarrass our government in its public duties, or endanger the person or injure the character of the agent." Id. at 106. See also 8 WIGMORE, op. cit. supra note $11, \S 2378(\mathrm{a})$. In Pollen v. United States, $85 \mathrm{Ct}$. Cl. 673, 681 (1937), the court said that the privilege against disclosure of military secrets "is predicated upon the principle of the public good, and the right of the Sovereign to maintain an efficient National defense-a public interest of such paramount importance as in and of itself transcends the individual interests of a private citizen." Other cases in which the privilege to withhold military secrets has been applied in derogation of private right are Pollen v. Ford Instrument Co., 26 F. Supp. 583 (E.D.N.Y. 1939) (a patent infringement suit wherein the court denied a motion for the production of drawings showing the construction of certain apparatus for the Navy); and Firth Sterling Steel Co. v. Bethlehem Steel Co., 199 Fed. 353 (E.D. Pa. 1912) (exhibits relating to drawings of an armor-piercing projectile manufactured for the Navy expunged from the record). But see Bank Line Ltd. v. United States, 68 F. Supp. 587 (S.D.N.Y. 1946) (an order requiring the production of a record of the United States Board of Investigation relating to a collision between ships at Casainformation which the Government withholds from the public see Parks, Secrecy and presently involved"). For a detailed discussion of the various kinds of military information which the Government withholds from the public see Parks, Secrecy and the Public Interest in Military Affairs, 26 GEo. WASH. L. REv. 23 (1957).

46. Chicago \& So. Air Lines v. Waterman S.S. Corp., 333 U.S. 103 (1948); United States v. Curtiss-Wright Export Corp., 299 U.S. 304, 320 (1936).

47. 248 F.2d 561 (D.C. Cir. 1957), rewd on other grounds sub nom. Kent v. Dulles, 357 U.S. 116 (1958).

48. $I d$. at 565 .

49. Id. at 567 .

50. Judges Bazelon, Edgerton and Fahy dissented, writing separate opinions. Aside from the statutory and constitutional questions raised, it is doubtful that an individual's purported communist associations had a real bearing on the conduct of foreign affairs by the State Department. See also Dayton v. Dulles, 254 F.2d 71 (D.C. Cir. 1957), rev'd on other grounds, 357 U.S. 144 (1958). See Republic of China v. National Union Fire Ins. Co., 142 F. Supp. 551 (D.C. Md. 1956) (communications between Department of State and British Foreign Office held privileged). 
When limited to the subjects of military and international affairs there should be relatively little difficulty in applying the secrets of state privilege. Unfortunately, courts are sometimes persuaded to attach the secrets of state label to unrelated matters, and thus dissipate the value of a rather clear-cut distinction.

\section{The Informer Privilege}

A full and informative statement of the common-law "informer privilege," namely, the government's right to withhold the identity of one who furnishes information of a violation of law, and sometimes the content of his information, was recently made by Mr. Justice Burton in Roviaro $v$. United States ${ }^{51}$ as follows:

"What is usually referred to as the informer's privilege is in reality the Government's privilege to withhold from disclosure the identity of persons who furnish information of violations of law to officers charged with enforcement of that law. Scher $v$. United States, 305 U.S. 251, 254; In re Quarles and Butler, 158 U.S. 532; Vogel v. Gruaz, 110 U.S. 311, 316. The purpose of the privilege is the furtherance and protection of the public interest in effective law enforcement. The privilege recognizes the obligation of citizens to communicate their knowledge of the commission of crimes to law-enforcement officials and, by preserving their anonymity, encourages them to perform that obligation.

"The scope of the privilege is limited by its underlying purpose. Thus, where the disclosure of the contents of a communication will not tend to reveal the identity of an informer, the contents are not privileged. Likewise, once the identity of the informer has been disclosed to those who would have cause to resent the communication, the privilege is no longer applicable.

"A further limitation on the applicability of the privilege arises from the fundamental requirements of fairness. Where the disclosure of an informer's identity, or of the contents of his communication, is relevant and helpful to the defense of an accused, or is essential to a fair determination of a cause, the privilege must give way. In these situations the trial court may require disclosure and, if the Government withholds the information, dismiss the action. . .

"We believe that no fixed rule with respect to disclosure is justifiable. The problem is one that calls for balancing the public interest in protecting the flow of information against the individual's right to prepare his defense. Whether a proper balance renders nondisclosure erroneous must depend on the particular circumstances of each case, taking into consideration the crime 
charged, the possible defenses, the possible significance of the informer's testimony, and other relevant factors." 52

There is little that can be added to this, except to note that the Court actually held in the Roviaro case that the privilege was not there available because it was sought on behalf of one who actively participated in the investigative process, leading to the apprehension of the defendant. One who is such a participant is not protected by the informer privilege, the Court said, and the Government must disclose his identity to the defense in the course of the prosecution for the crime investigated. The essence of Roviaro seems to be that it lies within the discretion of the court to determine whether the informer privilege is available in a criminal prosecution after "balancing the public interest in protecting the flow of information against the individual's right to prepare his defense." 53

Implicit in the Roviaro decision is a theory of waiver arrived at by an examination of the underlying purpose of the informer privilege. Once an individual takes it upon himself to step out of the role of simply transmitting information to a law enforcement officer, ${ }^{54}$ he elects to give up the right of anonymity with which the privilege clothes him. ${ }^{65}$

There is very little authority on the applicability of the informer privilege to civil cases, although "violations of law" may be of a civil nature which administrative agencies have a duty of policing, as for instance, unfair labor practices by the National Labor Relations Board. The fact that the violator on the one hand generally is not seeking to hide, and the injured party on the other, is likely to seek redress, limits the need for encouraging the flow of this kind of informa-

52. Id. at 59-62. The Uniform Rules of Evidence define the privilege as follows: "Rule 36. Identity of Informer. A witness has a privilege to refuse to disclose the identity of a person who has furnished information purporting to disclose a violation of a provision of the laws of this State or of the United States to a representative of the State or the United States or a governmental division thereof, charged with the duty of enforcing that provision, and evidence thereof is inadmissible, unless the judge finds that (a) the identity of the person furnishing the information has already been otherwise disclosed, or (b) disclosure of his identity is essential to assure a fair determination of the issues."

53. The difficulty of exercising such discretion was manifested in a recent decision by the Supreme Court of California, where a divided court held that a policeman is required to disclose the names of informers whose information led to a search, without a warrant, of a narcotic suspect's home. Only if such identity is disclosed, the court feit, can it make a fair determination of the reasonableness of the search. Dissenting judges maintained that it did not come within the scope of the Roviaro case because the informer was not a participant. Priestly v. Superior Court, 330 P.2d 39 (Cal. Sup. Ct. 1958). See text following note 57 infra.

54. See People v. Roban, 45 N.Y.S.2d 213 (Magis. Ct. 1943) (In a prosecution for sending threatening letters, the government is privileged not to disclose the identity of an informer who wrote to the Police Department accusing complainant of prostitution.). . Contra, Priestly v. Superior Ct., supra note 53.

55. As Mr. Justice Burton pointed out in the Roviaro case, once the identity of the informer has been disclosed the privilege is no longer available. 353 U.S. at 60 , citing the following cases: Sorrentino v. United States, 163 F.2d 627 (9th Cir. 1947); Pihl v. Morris, 319 Mass. 577, 66 N.E.2d 804 (1946). 
tion to the agencies. However, the issue has arisen in several antitrust suits, where it was held that the informer privilege was available to the Government, mainly on the ground that such a proceeding was comparable to a criminal action. ${ }^{58}$ More recently, though, it has been narrowly construed and found unavailable where the "statements would not embarrass the informants in their social relations or their employment or endanger their safety" and the Government voluntarily disclosed the names. ${ }^{57}$

\section{Information Obtained by Investigation}

Closely related to the information which is protected by the fairly well defined informer privilege, but distinguishable from it in a material way, is information assembled by agencies by investigation. In the investigative process, unsolicited information from dutiful citizens is a negligible factor. It mainly includes information obtained either by members of the agency staff, paid operatives, or voluntary participants in the actual investigation. The question often arises whether persons who are affected by an investigation or who, in litigation, can further

56. United States v. Deere \& Co., 9 F.R.D. 523 (D. Minn. 1949). The United States instituted an injunction proceeding against Deere under the antitrust laws charging that Deere sought to compel dealers in its farm implements to handle only its own line of machinery and cancelled contracts of dealers who refused to comply. The Government counsel had sent a five-page questionnaire to each of defendant's former dealers. Defendant moved, under rule 34 of Federal Rules of Civil Procedure, to compel the Government to permit defendant to inspect copies of all the answers received from the former dealers. The motion was denied by the district court. "The considerations which require the withholding of information and its source, from the accused by the Government in criminal cases, are present also in anti-trust actions brought for the public interest by the Government." Id. at 526. See also United States v. Kohler Co., 9 F.R.D. 289 (E.D. Pa. 1949). In the Deere case the court went beyond the accepted limits of the common-law privilege, since the defendant contended that the names of the informants were already known. Nevertheless the court held that to divulge the information would destroy the "confidential relationship between the Government and its informants and seriously impede the Government's efforts in other similar investigations." United States v. Deere \& Co., supra at 527. Accord, Lewis v. Roux Trucking Corp., 222 App. Div. 204, 226 N.Y. Supp. 70 (1927). This was a negligence action where one of the parties made an application to inspect the records of the District Attorney, who was not a party to the action, to produce reports filed in his office of investigations of the accident, which reports had been made for the purpose of determining whether a crime had been committed. Despite the fact that the informants were known to all parties, the court upheld the assertion of governmental privilege, saying, "The injury to be apprehended to the public interest from not following that course is greater than the injury which may accrue to the private individuals seeking justice as a result of denying to them access to the public prosecutor's memoranda." Id. at 212, 226 N.Y. Supp. at 79. This decision has been strongly criticized by Professor Wigmore. 8 WIGMORE, EvIDENCE $\$ 775$ (3d ed. 1940). But see Application of Heller, 184 Misc. 75, 53 N.Y.S.2d 86 (Sup. Ct. 1945). In a habeas corpus proceeding to determine the custody of a child a subpoena duces tecum was served on the District Attorney for New York County requiring him to produce records of certain conversations of persons related to the case. The District Attorney's assertion of privilege was denied and the motion to inspect the records was granted, the court saying that the informer privilege was a qualified privilege and depended upon the public safety. Since in this case there was no element of public safety, the privilege was held not to be available.

57. Mitchell v. Bass, 252 F.2d 513 (8th Cir. 1958). 
their causes by disclosure of the information assembled, may be barred from obtaining it by an agency privilege of nondisclosure.

In the Roviaro case the Supreme Court made clear that information obtained by investigation, when relevant to the defense in a criminal prosecution, is not protected by the informer privilege. The petitioner in that case had been convicted for knowingly possessing and transporting heroin imported unlawfully. He was apprehended as a result of the cooperation with the police of an undercover informer who had directed the police to the place where the petitioner delivered the heroin and had himself been the recipient of the heroin from the accused. Before and during the trial the accused's attorney sought the disclosure of the identity of this informer but the trial court denied the applications on the basis of the informer privilege and the court of appeals affirmed. But the Supreme Court reversed these decisions on the ground that the informer privilege was inapplicable because "the Government's informer was the sole participant other than the accused, in the transaction charged." 58 By thus becoming a participant in the investigative process, the underlying purpose of the informer privilege, namely, the encouragement of private citizens to bring to the attention of law enforcement officers violations of law is dissolved. It is noteworthy that the Court did not apply the so-called "official information" privilege, of which more will be said shortly.

The rule in the Roviaro case was carried one step further by the New Jersey Supreme Court, which recently held that where the participant in the investigative process was a paid functionary, he is not a proper person on whose behalf the informer privilege can be invoked. ${ }^{59}$ That was an action for a declaratory judgment and for an injunction brought by a county attorney to restrain a legislative committee investigating wire-tapping from requiring the disclosure of the identity of persons employed by him as wire-tappers, as well as the information obtained by them. The court held that the common-law informer privilege was not available on behalf of persons who were "outside" operatives for the county attorney.

At about the same time the United States Supreme Court ruled in the Jencks case that, in a criminal prosecution, the written reports of paid operatives of the FBI who testified at the trial and touching the events and activities as to which they testified were not privileged and must be produced upon the application of the defendant. The right to

58. 353 U.S. at 64. But see People v. Alaniz, 149 Cal. App. 2d 560, 309 P.2d 71 (Dist. Ct. App. 1957). In a prosecution for the unlawful possession of heroin, the court upheld the Government's claim of privilege not to disclose the identity of an informer.

59. Morss v. Forbes, 24 N.J. 341, 132 A.2d 1 (1957). 
such disclosure, as we have seen, has now also been applied in civil cases. ${ }^{60}$

To what extent, it may be asked, are such rules inconsistent with the so-called "official information" privilege that is said to have common law origins? ${ }^{\text {i1 }}$ If, for the moment, we subtract from such official information communications relating to internal management, a subject discussed in the following section, is there anything left? The remainder is a no man's land that can only be described as information that should be privileged because an agency asserts that it is in the "public interest" to do so. ${ }^{62}$ Except in several instances where statutes so provide, ${ }^{63}$ in very few cases has this been a basis for consideration by the courts independently of more specifically identified privileges. ${ }^{64}$ In 1927, the United States Supreme Court refused to recognize a claim of privilege broadly based on the public interest. The issue in the case was whether the Commissioner of Internal Revenue could be required by subpoena duces tecum to make available to a taxpayer information contained in the tax returns of twelve corporations similarly situated and who had received certain statutory benefits not made available to the taxpayer. The Court held that, even though the information was made confidential by statute, a privilege was not available when its disclosure was necessary in a judicial proceeding. ${ }^{65}$

It may well be that most of such information would, in a judicial proceeding, be held incompetent on hearsay grounds, and therefore

60. Communist Party v. Subversive Activities Control Bd., 254 F.2d 314 (D.C. Cir. 1958) ; NLRB v. Ad̉esive Prod. Corp., 258 F.2d 403 (2d Cir. 1958).

61. Uniform Rules of Evidence define this as follows: "Rule 34. Official Information. (1) As used in this rule, 'official information' means information not open or theretofore officially disclosed to the public relating to internal affairs of this state or of the United States acquired by a public official of this State or the United States in the course of his duty, or transmitted from one such official to another in the course of duty. (2) A witness has a privilege to refuse to disclose a matter on the ground that it is official information, and evidence of the matter is inadmissible if the judge finds that the matter is official information, and (a) disclosure is forbidden by an Act of Congress of the United States or a statute by the State, or (b) disclosure of the information in the action will be harmful to the interests of the government of which the witness is an officer in its governmental capacity."

62. See Judge Maris' opinion in Reynolds v. United States, 192 F.2d 987 (3d Cir. 1951), rev'd, 345 U.S. 1 (1953). In reviewing the various common-law privileges, he said: "[T] $[\mathrm{T}$ here is also a less clearly defined privilege against disclosing official information if such disclosure will actually be harmful to the interests of the nation." Id. at 994. In England, it might be noted, such a "public interest" standard is applicable and has been strongly criticized. ALLEN, LAW AND ORDERS 370 (2d ed. 1956).

63. See Jessup v. Superior Court, 151 Cal. App. 2d 102, 311 P.2d 177 (Dist. Ct. App. 1957), applying the provision of the California Code of Civil Procedure prohibiting disclosure "when the public interest would suffer."

64. See United States v. Deere \& Co., 9 F.R.D. 523 (D. Minn. 1949), and United States v. Kohler Co., 9 F.R.D. 289 (E.D. Pa. 1949).

65. Blair v. Oesterlein, 275 U.S. 220 (1927). See also Bowles v. Ackerman, 4 F.R.D. 260 (S.D.N.Y. 1945). In an action by Price Administrator to enjoin violation of maximum price order, information obtained from defendant by investigators is not privileged. 
unavailable to the litigant in any event. Judge Prettyman, in the Communist Party case, on this ground, excluded the reports of a witness which were not written by the witness, but were accounts of conversations of the witness reported by others. ${ }^{66}$

Another element which occasionally arises in connection with "official information" is information received by an agency "in confidence." This may refer to such subjects as are made confidential by statute, and also information provided by an informer. Information furnished by staff members, paid operatives, and other participants in the investigative process is, we assume, "in confidence," but as the Roviaro and Jencks cases show, this fact alone does not create a privilege. $^{67}$

The net result appears to be that information obtained by investigation is not privileged per se. Its various aspects, however, have not been fully explored and it would be premature to assert that no privilege at all is available to the government. It is quite possible that an agency can satisfy a court that in a particular case disclosure would be, on balance, more harmful to the interests of the state than the resultant injury to the party seeking the information. The courts may find it easier to reach a decision where they can start with some identifiable privileged subject matter, such as secrets of state. In the circumstances here presented, however, they must make the determination without such assistance.

\section{Communications Relating to Internal Management of Agencies}

One side result of the notorious Army-McCarthy hearings in 1954 was the focusing of attention on one of the more perplexing of the privileged communications problems, namely, the right to withhold information "transmitted from one such (public) official to another in the course of duty." 88 At the hearings, a letter dated May 17, 1954, from President Eisenhower to the Secretary of Defense, was introduced, together with a supporting memorandum of law by the Attorney General, the letter stating in part as follows:

66. Communist Party v. Subversive Activities Control Bd., 254 F.2d 314, 325 (D.C. Cir. 1958).

67. "There is a vast difference between confidential and privileged. Almost any communication, even an ordinary letter, may be confidential. . . But privileged means that the contents are of such character that the law as a matter of public policy protects them against disclosure. A communication from a person to his banker may be confidential, but it is not privileged; certain of his communications to his doctor or his lawyer are not only confidential but also privileged; the law does not permit their disclosure even under subpoena by a court." Judge Prettyman, in Communist Party v. Subversive Activities Control Bd., 254 F.2d 314, 321 (D.C. Cir. 1958).

68. Uniform Rules of Evidence 34. Moded Code of Evidence rule 228 (1942). 
"Because it is essential to efficient and effective administration that employees of the Executive branch be in a position to be completely candid in advising with each other on official matters, and because it is not in the public interest that any of their conversations or communications, or any documents or reproductions, concerning such advice be disclosed, you will instruct employees of your department that in all of their appearances before the Subcommittee of the Senate Committee on Government Operations, regarding the inquiry now before it, they are not to testify to any such conversations or communications or to produce any such documents or reproductions. This principle must be maintained regardless of who would be benefited by such disclosures.

"I direct this action so as to maintain the proper separation of powers between the Executive and Legislative branches of the Government in accordance with my responsibilities and duties under the Constitution. This separation is vital to preclude the exercise of arbitrary power by any branch of the Government." ${ }^{89}$

These instructions raise two distinct problems. First, they have been loosely referred to as an exercise of the "executive privilege," 70 meaning the more or less well recognized right of a chief executive, the President of the United States, or the governor of a state, to withhold information in his possession. ${ }^{71}$ The second problem, and the one which concerns us here, involves the internal management of agencies; namely, their right to withhold from litigants pertinent intra- and inter-departmental communications among administrative officials. Such communications might deal with personnel matters, budgetary information, advice given by a subordinate official to a superior, consultations amongst associates or exchanges of information among different departments. These communications may have a definite bearing on action to be taken with respect to outside persons or be mainly of an administrative or "housekeeping" kind. ${ }^{72}$

The right to withhold such information in judicial proceedings is a subject that has, until recently, received only perfunctory treatment

69. N.Y. Times, May 18, 1954, p. 24, col. 1. Although this communication is concerned with disclosure of information in congressional hearings, it probably would be asserted also in a judicial proceeding. Despite the fact that this communication was directed specifically to the Secretary of Defense, nineteen departments and agencies of the federal government reported that they based their authority to restrict or withhold information on this letter. H.R. REP. No. 2947, 84th Cong., 2d Sess. 65 (1956). See also President Eisenhower's letter of Jan. 22, 1958, N.Y. Times, Jan. 23, 1958, p. 10, col. 3.

70. H.R. RFP. No. 2947, 84th Cong., 2d Sess. 66 (1956).

71. See note 19 supra.

72. See H.R. REP. No. 2947, 84th Cong., 2d Sess. 66, 107 (1956), for a breakdown of the various types of information to which federal departments attach restrictions. See also Bank Line Ltd. v. United States, 76 F. Supp. 801 (S.D.N.Y. 1948). The court would not accept a contention that a record of an investigation of a collision between ships was "housekeeping" information entitled to a privilege of nondisclosure. 
by the courts in the United States. Zacher $v$. United States, ${ }^{73}$ for instance, involved a communication from a United States attorney to the Attorney General recommending that a pending prosecution for filing a fraudulent income tax return be dropped. Defendant's attorney sought, by subpoena duces tecum, to have the letter produced, but the court upheld the quashing of the subpoena, saying only: "It seems clear that the letter to the Attorney General was a confidential and privileged communication, and accordingly the motion to suppress was properly sustained." 74

President Eisenhower's letter was mainly concerned with communications relating to exchanges of advice among Government officials, which is probably the most sensitive of the internal management areas.

This problem was recently dealt with by Mr. Justice Reed, sitting by assignment in the Court of Claims. ${ }^{75}$ The case involved an action for damages by an aluminum company against the United States, acting through the Liquidator of War Assets, for breach of contract. It was alleged that, in violation of a most-favored-purchaser clause in the contract, aluminum plants were sold by the Government to plaintiff's competitors on better terms than to plaintiff. An application was made for the Government to produce an advisory memorandum made by a member of the staff to the Liquidator of War Assets concerning these sales. The Government refused to produce this document and filed a formal claim of privilege. Mr. Justice Reed upheld this claim on the ground that it was contrary to public interest to compel the disclosure of an advisory opinion on intra-office policy. He said:

"Free and open comments on the advantages and disadvantages of a proposed course of governmental management would be adversely affected if the civil servant or executive assistant were compelled by publicity to bear the blame for error or bad judgment properly chargeable to the responsible individual with the power to decide and act. Government from its nature has necessarily been granted a certain freedom from control beyond that given the citizen. It is true that it now submits itself to suit but it must retain privileges for the good of all.

"There is a public policy involved in this claim of privilege for this advisory opinion-the policy of open, frank discussion between subordinate and chief concerning administrative action." 78

73. 227 F.2d 219 (8th Cir. 1955), cert. denied, 350 U.S. 993 (1955).

74. $I d$. at 226. 1958).

75. Kaiser Aluminum \& Chem. Corp. v. United States, 157 F. Supp. 939 (Ct. Cl.

76. Id. at 945-46. See also the Canadian case of Reese v. The Queen [1955] Can. Exch. 187, [1955] 3 D.L.R. 2d 691. In that case a veteran had made an agreement with a Government agency for the purchase of certain lands as well as the 
Another aspect of the internal affairs privilege is the question of the availability to litigants of pertinent information contained in government files. Although such material may in any event be excluded on hearsay grounds, some cases that have dealt with the issue take the unelaborated position that it is privileged. ${ }^{77}$

But in the Communist Party case the court made a deep inroad into such a privilege, if indeed there is one, by holding that where the "records of an executive department maintained in the course of carrying out its functions" are shown to contain evidence contradictory to the testimony of a government witness, such records must be produced upon the request of an opposing party. The particular records in that case were those concerning the compensation paid by the Government to the witness as an informer. ${ }^{78}$

This is undoubtedly further than any court has gone on this question. It does not entirely destroy the right of an agency to withhold information of a "housekeeping" nature, but it underlines the principle that where the disclosure of such information, in a particular instance, cannot be shown to be harmful to the agency, its disclosure will be required.

mineral rights in such land. In an action on the agreement by successors in interest it was necessary to prove that the agency had the right to make the sale, and this proof was contained in certain documents and letters exchanged between different agencies and by divisions of the same agency. A motion for the production of these documents was denied on the ground that it was contrary to the public interest to compel the disclosure of inter-departmental correspondence. Said the court: "If they [communications between officials] were made with the knowledge that they might later be subject to disclosure in the Courts, they would in many cases be shorn of that candor, completeness and freedom of expression which is desirable in such matters. They would tend to become more cautious and reserved and expressions of opinion would be affected by the possibility of subsequent public disclosure. The officials of the state would be hampered in the performance of their proper functions." Id. at 197, [1955] 3 D.L.R. at 701. See Willis, Discovery Against Crozen in Right of Canada When Defendant in Civil Proceeding, 33 CaN. B. Rev. 1186 (1955).

77. Universal Airlines, Inc. v. Eastern Airlines, Inc., 188 F.2d 993 (D.C. Cir. 1951). Said the court: "The Board [CAB] contends, however, that it is an error to compel an agent of the Board to produce any of the Board's reports, orders or private files or to testify as to the contents of such private papers. This contention seems sound and supported by the authorities." Id. at 1000. No authorities, however, are cited. But see Bowles v. Ackerman, 4 F.R.D. 260 (S.D.N.Y. 1945). Where the Price Administrator brings an action to enjoin the violation of a maximum price order and for penalties, the defendant has the right to examine an attorney in the office of the Price Administrator with respect to information in his files pertaining to the defendant.

78. Communist Party v. Subversive Activities Control Bd, 254 F.2d 314 (D.C. Cir. 1958). "We do not rely upon Jencks v. United States, supra, or Public Law No. 85-269 for our conclusion that the records of Markward's compensation from the F.B.I. must be produced, since these records are not 'statements' of the witness but are rather records of an executive department maintained in the course of carrying out its functions. Our conclusion is based on the general proposition, exemplified by Rule 34 of the Federal Rules of Civil Procedure, that, where one party to an action is shown to have documentary evidence contradictory to the testimony of one of its witnesses, production of such documents is required upon request of an opposing party." Id. at 330 . 


\section{Information Furnished by Persons as Required by Statute ${ }^{70}$}

The extension of governmental activities into the areas of employment, health, relief, increased taxation and the like made it essential that information relating to these matters be obtained from affected persons and organizations. The applicable statutes therefore require such information to be furnished, but, because of the difficult enforcement problems that would result from a reluctance on the part of individuals to make public matters they consider of a private nature, the disclosure of the data is restricted or barred to encourage cooperation. ${ }^{80}$

The degree of restriction varies in the many applicable statutes. In most cases the statute simply classifies the information as confidential, which is sufficient to exclude the public from access to it; but such a classification does not constitute a basis for a right to refuse disclosure in judicial proceedings. ${ }^{81}$ In some instances, however, the statutes recognize that the issue of privilege may arise in judicial proceedings. Thus, it is sometimes provided that the confidential information is to be made available in any litigation upon the service of a subpoena duces tecum; ${ }^{82}$ or it is to be made available only where the agency itself is a party to the action; ${ }^{83}$ or that it is to be excluded even where required in judicial proceedings. ${ }^{84}$

79. An exhaustive collection of statutory materials on this subject appears in 8 Wigmore, Evidence $\$ 2377$ (3d ed. 1940, Supp 1957).

80. Professor Wigmore explains it as follows: "[M]any situations exist where the information can best be obtained only from the person himself whose affairs are desired to be known by the Government. An attempt to do so by mere compulsion might be tedious and ineffective. And where the ultimate purpose to be served is administrative, and not penal, it may well be that the Government can afford to promise secrecy in respect to purposes penal or litigious, as the price of readily achieving its administrative purpose when it demands a report of the truths.

"It is some such principle that justifies the modern creation of a number of privileges, all statutory in origin, covering sundry matters required by law to be reported to some administrative official." \& WIGMORE, EVIDENCE $\$ 2377$, at 761 (3d ed. 1940).

81. Blair v. Oesterlein Co., 275 U.S. 220 (1927).

82. See Marceau v. Orange Realty, Inc., 97 N.H. 497, 92 A.2d 656 (1952).

83. The New York Unemployment Insurance Law provides as follows: "Information acquired from employers or employees pursuant to this article shall be for the exclusive use and information of the commissioner in the discharge of his duties hereunder and shall not be open to the public nor be used in any court in any action or proceeding pending therein unless the commissioner is a party to such action or proceeding, notwithstanding any other provision of law." N.Y. LAB. LAW \$537. This section was applied in Eston v. Backer, 204 Misc. 162, 119 N.Y.S.2d 273 (Sup. Ct. 1953).

84. See In re Bakers Mut. Ins. Co., 301 N.Y. 21, 92 N.E.2d 49 (1950), which involved a provision of the Sanitary Code of the City of New York requiring that physicians file certificates of death and separate confidential medical reports indicating the cause of death, which reports "shall be regarded and treated as a confidential and privileged communication, and shall not be subject to subpoena or open to inspection for any reason whatsoever, other than for scientific purposes approved by the Board of Health." The court indicated that such a statute did not raise a constitutional question. 
Since there does not appear to be any correlation between the type of statute and the nature of the subject matter, we indicate the various categories of subjects which may be classed as confidential, insofar as the public alone is concerned, and also those to which there may be a right of nondisclosure in judicial proceedings.

The restrictions are placed on information provided by individuals as required by law with respect to income tax returns and other tax information, ${ }^{85}$ trade secrets and names of customers, ${ }^{86}$ applications for patents, ${ }^{87}$ records relating to the regulation of business, utilities and banks, ${ }^{88}$ information relating to the mediation of labor disputes, ${ }^{89}$ accident reports, ${ }^{90}$ records relating to public health, ${ }^{91}$ and records of

85. See N.Y. TAx LAw \$202. "Secrecy Required of Officials . . . Except in accordance with proper judicial order or as otherwise provided by law, it shall be unlawful for any tax commissioner, or officer or employee of the department of taxation and finance, . . . to divulge or make known in any manner the amount of income or any particulars set forth or disclosed in any report under this article." A federal statute provides that after the income tax has been determined, the returns "shall be public records" but may be inspected only upon order of the President and under regulations of the Secretary of Treasury. 53 Stat. 29 (1940), 26 U.S.C. \$ 55 (1952). See Lewy v. United States, 29 F.2d 462 (7th Cir. 1928) (an original tax return may be furnished to the United States Attorney for use in court). See also In re Estate of Fife, 164 Ohio St. 449, 132 N.E.2d 185 (1956) (Rev. Code of Ohio \$ 5711.11, providing that "returns filed with county auditor showing income yield of productive investments or taxable property shall not be open for public inspection," held not to prohibit the issuance of a subpoena for the returns and their introduction as evidence.)

86. 38 Stat. 721 (1914), 15 U.S.C. \$ $46(f)$ (1952).

87. 35 U.S.C. $\$ 122$ (1952).

88. See The Pennsylvania Securities Act, PA, Stat. ANn. tit. 70, §53 (Supp. 1957). "Disclosure of Information forbidden . . . Neither the members of the commission nor the secretary . . . or other employe of the commission, shall publish or divulge to any one any information contained in or ascertained from any examination or investigation made by the commission, or any letter, report, or statement sent to the commission, or any other paper or document in the custody of the commission, except . . when the production of such information is required by subpoena or other legal process of a court of competent jurisdiction ...." See also the Rhode Island Uniform Aeronautical Regulatory Act, R.I. GEN. LAws tit. I, §1-4-13 (1956): "Reports of hearings and investigations as evidence-Testimony by director and administrator. The reports of investigations or hearings, or any part thereof, shall not be admitted in evidence or used for any purpose in any suit, action, or proceeding growing out of any matter referred to in such investigations or hearings, or in any report thereof, except in case of criminal or other proceedings instituted by or in behalf of the director under the provision of this chapter; nor shall either the director or the administrator of aeronautics be required to testify to any facts ascertained in, or information gained by reason of his official capacity." The Wisconsin Savings and Loan Association Law, Wrs. STAT. ANN. \$215.50(6) (1957), provides: "Disclosure of information; . . (a) The commissioner, and all other officers and employees of the savings and loan department, and members of the advisory committee shall keep secret all of the facts and information obtained in the course of examination... except when called as a witness in any criminal proceeding or trial in a court of justice ...."

89. See N.Y. LAB. LAW $\$ 753(3)$. "Members of the board [State Board of Mediation], the executive secretary and all other employees of the board shall not be compelled to disclose to any administrative or judicial tribunal any information relating to, or acquired in, the course of their official activities" in the mediation and negotiation of disputes between employers and employees.

90. See Ehrhardt v. Ruan Transp. Corp., 245 Iowa 193, 61 N.W.2d 696 (1953); Rockwood v. Pierce, 235 Minn. 519, 51 N.W.2d 670 (1952) (the court reviews statutes from several jurisdictions).

91. The N.Y. State Sanitary Code ch. 2, reg. 26 (PuB. Healtr Law) provides that records of the state or local departments of health relating to cases of cancroid, 
adoption and illegitimate births. ${ }^{22}$ In addition, disclosure is prohibited of welfare relief records, ${ }^{93}$ social security and unemployment insurance reports, ${ }^{94}$ records of claims for veterans' benefits ${ }^{95}$ and census information. ${ }^{96}$

Since the statutes restricting disclosure may cut down the evidence available in a judicial proceeding the courts have generally construed them narrowly and in the light of the underlying reasons for their enactment. If it appears that the basis for the privilege is not present then the courts have refused to recognize the claims of privilege. Several cases illustrate this.

In State ex rel. Haugland $v$. Smythe ${ }^{87}$ a judge before whom was pending a juvenile delinquency proceeding, issued a subpoena duces tecum to a county welfare administratrix requiring her to produce for his inspection certain files pertaining to the mother and grandparents of the delinquent boy. Both federal and state statutes restricted the disclosure of this information, and departmental regulations prohibited their production in response to a subpoena duces tecum. Nevertheless, the highest court of the state upheld the issuance of a subpoena on the

gonorrhea or syphilis "shall be confidential" and shall not be disclosed "except insofar as is necessary to serve the best interest of the patient or his family, or contribute to the protection of the public health." See Thomas v. Morris, 286 N.Y. 266, 36 N.E.2d 141 (1941) (records relating to a "typhoid carrier," whose disclosure is restricted by the Public Health Law and Security Code, made available to plaintiff in action for negligence against the defendant typhoid carrier).

92. N.Y. DoM. REL. LAW \$114. "The written report of the investigation together with all other papers pertaining to the adoption . . . must be sealed by him ljudge or surrogate] and withheld from inspection. . . . No order for access and inspection shall be granted except on due notice to the foster parents and on good cause shown."

The UnIForm VITAL Statistics Act $\$ 23$ provides: "Disclosure of Records . . . (2) Disclosure of illegitimacy of birth or of information from which it can be ascertained, may be made only upon order of a court in a case where such information is necessary for the determination of personal or property rights and then only for such purpose."

93. See State ex rel. Haugland v. Smythe, 25 Wash. 2d 161, 169 P.2d 706 (1946).

94. See Marceau v. Orange Realty, Inc., 97 N.H. 497, 92 A.2d 656 (1952); Powers ex rel. Dep't of Employment Security v. Superior Court, 79 R.I. 63, 82 A.2d 885 (1951). See N.Y. LAB. LAW \$537, which prohibits use of information obtained from employers and employees pursuant to the unemployment insurance law "in any court .. . unless the commissioner is a party. . . "

95. See Veterans' Benefits Act of 1957, 71 Stat. 83, 38 U.S.C. $\$ 3201$ (Supp. V, 1958): "Sec. 1201. Confidential Nature of Claims. All files, records, reports and other papers and documents pertaining to any claim under any of the laws administered by the Veterans' Administration shall be confidential and privileged, and no disclosure thereof shall be made except as follows . . . (2) when required by process of a United States court to be produced in any suit or proceeding therein pending. . . ."

96. See 13 U.S.C. $\$ 8$ (Supp. V, 1958). "The Secretary may, upon a written request, and in his discretion, furnish . . courts of record .... data for genealogical purposes. . . (c) In no case shall information furnished under the authority of this section be used to the detriment of the persons to whom such information relates."

97. 25 Wash. 2d 161, 169 P.2d 706 (1946). 
ground that "the information sought by the Juvenile Court was for its own use. . . ." Such a disclosure, the court felt, was not an invasion of the privilege.

The same court went even further in another case in narrowing the application of the statutory privilege when, in a criminal prosecution for rape, it required the production of the files of the County Welfare Department pertaining to the prosecuting witness, not only for the examination of the court, but also in the judge's chambers by the attorneys for the prosecution and the defense. The court felt that constitutional due process so required. ${ }^{98}$

In contrast to this we find that the highest court of New York, in a civil case, held that a statute providing for nondisclosure of medical reports containing the causes of death will support a claim of privilege to withhold such a report, which is sought in a pending workmen's compensation action in which the cause of death was a material and pertinent fact. ${ }^{98}$

The most frequent litigation arising out of statutory privileges involves accident reports. Most states provide that such reports when made by a police investigation are confidential and unavailable in litigation. However, the question often arises whether the police officer making the investigation can be required to testify as to admissions made by one of the parties, not from his report, but from his own knowledge. The subject was examined fully by the Minnesota Supreme Court in Rockrood v. Pierce, ${ }^{100}$ which held that such testimony was not so privileged. ${ }^{101}$

Finally, in view of the nature of the privilege, it is generally held that the person who furnished the information may, by his own act, waive the privilege applicable to that information, and obtain it for his own use. ${ }^{102}$

\section{The Function of the Court in Determining Applicability of PrIVILEge}

Probably the most discussed, and still unresolved, problem of an agency's claim of privilege concerns the respective responsibilities of the agency and the court in deciding whether the privilege is properly claimed. There is considerable difference of opinion as to where the

98. State $e x$ rel. State v. Church, 35 Wash. $2 d$ 170, 211 P.2d 701 (1949).

99. In re Bakers Mut. Ins. Co., 301 N.Y. 21, 92 N.E.2d 49 (1950).

100. 235 Minn. 519, 51 N.W.2d 670 (1952).

101. Accord, Wallace v. Skrzycki, 338 Mich. 164, 61 N.W.2d 106 (1953); Universal Airlines, Inc. v. Eastern Airlines, Inc., 188 F.2d 993 (D.C. Cir. 1951). But see Ehrhardt v. Ruan Transp. Corp., 245 Iowa 193, 61 N.W.2d 696 (1953).

102. Baltimore \& O.R.R. v. Lykins, 216 F.2d 129 (6th Cir. 1954); Bowles v. Ackerman, 4 F.R.D. 260 (S.D.N.Y. 1945); Powers ex rel. Dep't of Employment

Security v. Superior Court, 79 R.I. 63, 82 A.2d 885 (1951). 
final authority is lodged, and a variety of procedural devices have been proposed to minimize the clash of interest between the courts and the agencies on this issue.

The primary question is whether an agency's claim of privilege precludes any judicial inquiry into the merits of the claim. The English rule is that it does, at least in civil cases. There, if the claim is made in proper form by the highest departmental officer on the ground that it would be contrary to the public interest to disclose the information, the courts have no alternative but to deny an application for its production. ${ }^{103}$ In the United States, however, the courts are unwilling to accord a similar "prerogative immunity" to agency claims. To this there is at least one recognized qualification. In the case of the President of the United States or the governor of a state, an assertion of "executive privilege" to withhold information on the general ground that it would be contrary to the public interest to disclose it, would most likely be upheld without the necessity of submission to the courts. ${ }^{104}$

Although several judicial opinions and writers have stated that lesser officials have a similar right, ${ }^{105}$ the Supreme Court has indicated that the question of privilege, when claimed by officials other than the President, is one for the courts to decide. In United States $v$. Reynolds, ${ }^{106} \mathrm{Mr}$. Chief Justice Vinson, for the majority of the Court, said: "The court itself must determine whether the circumstances are

103. Duncan v. Cammell, Laird \& Co., [1942] A.C. 624 . The rule in this case is criticized in ALLEN, LAw AND ORDERS 369 (1956); and Street, State Secrets-A Comparative Study, 14 MODERN L. Rev 121 (1951). The Canadian courts are said to have departed from the English rule. Willis, 33 CAN. B. Rev. 352 (1955), commenting on Regina v. Snider, [1954] Can. Sup. Ct. 479, [1954] 4 D.L.R. 483.

104. See note 19 supra. "The assertion of such a privilege by the Executive, vis-à-vis Congress, is a judicially undecided issue," said Mr. Justice Reed, sitting by assignment in the Court of Claims. Kaiser Aluminum \& Chem. Corp. v. United States, 157 F. Supp. 939, 944 n.7 (Ct. Cl. 1958). See also Bishop, The Executive's Right of Privacy: An Unresolved Constitutional Question, 66 YALE L.J. 477 (1957).

105. In Dayton v. Dulles, 254 F.2d 71, 77 (D.C. Cir. 1957), rev'd on other grounds, 357 U.S. 144 (1958), Judge Prettyman said that, where disclosure would adversely affect our internal security for the conduct of foreign affairs, "[T] he cases and common sense hold that the court cannot compel the Secretary [of State] to disclose information garnered by him in confidence in this area. If he need not disclose the information he has, the only other course is for the courts to accept his assertion that disclosure would be detrimental in the fields of highest importance entrusted to his exclusive care. We think we must follow that course." See also Shaughnessy v. United States ex rel. Mezei, 345 U.S. 206, 212 (1953), where the Court held that in an exclusion case the authority of the Attorney General is "final and conclusive" and that he "cannot be compelled to disclose the evidence underlying his determinations in an exclusion case. - " See also Timbers \& Cohen, Demands of Litigants for Government Information, 18 U. PITT. L. REv. 687, 709-15 (1957); Haydock, Some Evidentiary Problems Posed by Atomic Energy Security Requirements, 61 HaRv. L. REv. 468, 472-75 (1948).

106. 345 U.S. 1 (1953). In the lower court opinion in this case, on which the dissenting Justices Black, Frankfurter and Jackson based their dissent, Judge Maris stated: "[W] are satisfied that a claim of privilege against disclosing evidence relevant 
appropriate for the claim of privilege, and yet do so without forcing a disclosure of the very thing the privilege is designed to protect." 107 The case, however, was not decided on that issue. ${ }^{108}$ The Court held that where a claim of privilege indicated a "reasonable possibility" that privileged information is involved, the party seeking the information must show "necessity" for compelling production. Such necessity was not present in this case, said the majority, because the plaintiffs had not availed themselves of an offer by the Government to examine the witnesses whose statements were among the documents sought to be produced. ${ }^{109}$

to the issues in a pending law suit involves a justiciable question, traditionally within the competence of the courts, which is to be determined in accordance with the appropriate rules of evidence, upon the submission of the documents in question to the judge for his examination in camera. Such examination must obviously be $e x$ parte and in camera if the privilege is not to be lost in its assertion. But to hold that the head of an executive department of the Government in a suit to which the United States is a party may conclusively determine the Government's claim of privilege is to abdicate the judicial function and permit the executive branch of the government to infringe the independent province of the judiciary as laid down by the Constitution." Reynolds v. United States, 192 F.2d 987, 997 (3d Cir. 1951). See also McCormICK, EVIDENCE 307 (1954): "The determination of questions of fact and the applications of legal standards thereto in passing upon the admissibility of evidence and the validity of claims of evidential privilege are traditionally the responsibility of the judge." See Annot., 32 A.L.R.2d 391 (1953).

107. 345 U.S. at 8.

108. 345 U.S. at 11. This was a death action under the Federal Tort Claims Act ch. 753, 60 Stat. 842 (1946) (codified in scattered sections of 28 U.S.C.), brought by survivors of civilian observers who were killed in a crash of a military aircraft testing secret equipment. The plaintiffs moved, under rule 34 of the Federal Rules of Civil Procedure, for production of the Air Force's official accident investigations report and the statements of the three surviving crew members, taken in connection with the official investigations. The Government asserted that the requested information was privileged, and in the affidavit accompanying the formal claim of privilege offered to produce the three surviving crew members for examination by the plaintiffs. The district court, however, ordered the Government to produce the documents in order that the court might determine whether they contained privileged matter. The Government refused, so the court entered an order, under rule 37 (b) (2) (i), that the facts on the issue of negligence would be taken as established in plaintiffs favor, and, after a hearing to determine damages, final judgment was entered for the plaintiffs. The court of appeals affirmed. But the Supreme Court reversed on the ground that the plaintiffs failed to show "necessity" for the production of the documents, since they did not accept the offer of the Government to examine the three surviving crew members "which might have given respondents the evidence to make out their case without forcing a showdown on the claim of privilege." See also Kaiser Aluminum \& Chem. Corp. v. United States, 157 F. Supp. 939 (Ct. Cl. 1958).

109. It may be significant that the Reynolds case involved a discovery proceeding under rule 34, which conditions relief on a showing of "good cause." The "necessity" rule applied by the majority appears to be a judicial extension of that condition, where a claim of privilege is made. Said the Court, "[I] t was entirely proper to rule initially that petitioner had shown probable cause for discovery of the documents. Thereafter, when the formal claim of privilege was filed by the Secretary of the Air Force, under circumstances indicating a reasonable possibility that military secrets were involved, there was certainly a sufficient showing of privilege to cut off further demand for the documents on the showing of necessity for its compulsion that had then been made." 345 U.S. at 10-11. However, the "good cause" condition (and its judicial extension?) does not apply under rule 45 , where production of documents are demanded by subpoena for use at trial. It might be noted that a similar showing of "necessity" was found lacking in Hickman v. Taylor, 329 U.S. 495 (1947), a landmark case in federal discovery proceedings. 
In a sequel to the Reynolds case, arising in the Court of Appeals for the Eighth Circuit, the parties did avail themselves of a similar opportunity to examine witnesses whose statements to the Government were sought in a discovery proceeding but, upon the refusal of several of them to testify, the court ordered production, and held that no evidentiary privileges were available for the type of information withheld. Upon the refusal of the Government to comply with the order to produce, the Government's action was dismissed. ${ }^{110}$

On the issue of whether the courts rather than the agencies should decide the availability of privilege, it is argued that the courts may not be expert enough to make a proper determination, particularly where highly technical data is involved; ${ }^{111}$ that the administrative officials can be trusted not to withhold information irresponsibly; ${ }^{112}$ and that disclosure to the court creates unwarranted risks where top secret information is involved. ${ }^{113}$

In reply it is maintained that judges are capable of dealing with technical data, for they are regularly confronted with all kinds; ${ }^{114}$ that agencies are likely to be overcautious and thus withhold too much information; ${ }^{115}$ and that the caliber of men who are judges minimizes any risk of unwarranted disclosure. ${ }^{116}$ While none of these arguments

110. Mitchell v. Bass, 252 F.2d 513 (8th Cir. 1958). This was an action instituted by the Secretary of Labor to enjoin violations of minimum wage, overtime, and record-keeping provisions of the Fair Labor Standards Act. The defendants moved, under rule 34 , for the production of statements made by eleven of defendant's employees to the Secretary's investigators. The motion was denied on the ground that good cause had not been shown, as required by rule 34, since the defendant knew the names and could get statements from the witnesses. Thereupon the defendant tried to obtain the statements, but four of the witnesses refused $\mathrm{He}$ then renewed the motion to produce the statements of these four witnesses, but the Secretary claimed they were privileged. The court overruled the claim of privilege, finding that neither the informer privilege nor an "executive" privilege applied, and ordered production of the statements. Upon the Secretary's refusal to produce, the action was dismissed pursuant to rule 37 (b) (2) (iii).

111. See Haydock, Some Evidentiary Problems Posed by Atomic Energy Security Requirements, 61 HARv. L. REv. 468, 475 (1948).

112. See Timbers \& Cohen, Deynands of Litigants for Government Information, 18 U. PITT. L. REv. 687, 708-09: "Government officials should not be, and rarely are, insensitive to the public interest in the rendition of justice in a courtroom. Where there is a real need for the information sought-because it is essential to the proper determination of the case and appears to be unavailable elsewhere-they should and generally do cooperate to the fullest possible extent consistent with the preservation of the integrity of investigative and law enforcement processes, for the protection of other public interests." But see AlLEN, LAW AND ORDERS 371 (1956), wherein he discussed "the usual assurances . . . given that Ministers and departments could be trusted to use the privilege with fairness and discretion." In answer to this he said: "It never seems to be realised when this soothing-syrup is administered that "abuse of power' does not consist only in gross, unscrupulous excess of it, but also in gradual and often well-meaning extension, in a timorous rather than an aggressive spirit."

113. Haydock, supra note 111, at 475 .

114. MCCORMTCK, EVIDENCE 307 (1954).

115. Ibid.

116. Ibid. 
is entirely persuasive, the scales, it seems to the author, are tipped in favor of having the courts make the ultimate determination since (1) they can appraise the claim of privilege with relative objectivity as compared with any agency evaluation, and (2) the manner in which the discretion can be exercised can minimize, to a great extent, any added risk of disclosure.

Accepting the principle that the courts have the final say as to whether particular information is privileged, several procedural devices have been applied or proposed to limit disclosure of allegedly confidential or secret information. Thus, the information can be examined ex parte and in camera. ${ }^{117}$ To the argument that this is not due process, it is maintained that it is at least better than no judicial examination at all. ${ }^{118}$ In some instances it is urged that in camera examination should be conducted in the presence of counsel. ${ }^{119}$ In addition, there are precedents for conducting a trial in the presence of all parties, with the public excluded. ${ }^{120}$

In camera proceedings in criminal trials were specifically disapproved by the Supreme Court in the Jencks case. ${ }^{121}$ This was probably done in recognition of the provision of the sixth amendment requiring a "public trial" in "all criminal prosecutions." If the due process clauses do not require such a public trial in civil cases, and some form of in camera proceedings are utilized to determine whether certain information is of a privileged type, a minimum requirement should be the presence of opposing counsel. Less than that, such as ex parte determination by the court and government counsel, could not be reconciled with our standards of fair procedure. If, under these circumstances, the government finds it still cannot risk such limited disclosure, the standards should not be further compromised, but the court should, as in the Jencks case, rule against the government on the issues raised. ${ }^{122}$ In weighing the rights of disclosure, even in appropriate in camera proceedings, the agency, of course, must consider a possible appeal from a ruling in its favor. In such a case, the opposing

117. See Cresmer v. United States, 9 F.R.D. 203 (E.D.N.Y. 1949). See also the opinion of Judge Maris in Reynolds v. United States, quoted supra note 106.

118. Haydock, supra note 111, at 474.

119. See United States v. Cotton Valley Operators Comm., 9 F.R.D. 719 (W.D. La.), aff'd by an equally divided Court, 339 U.S. 940 (1949). 'See also State ex rel. State v. Church, 35 Wash. 2d 170, 211 P.2d 701 (1949).

120. See Haydock, supra note 111, at 482 .

121. "The practice of producing government documents to the trial judge for his determination of relevancy and materiality, without hearing the accused, is disapproved." 353 U.S. 657,669 (1957). But see $\$ 3500$ (c) of the post-Jencks statute: 18 U.S.C. $\S 3500$ (c) (Supp. V, 1958).

122. See United States v. Cotton Valley Operators Comm., 9 F.R.D. 719 (W.D. Ia.), aff'd by an equally divided Court, 339 U.S. 940 (1949). 
party undoubtedly has the right of appeal, but disclosure could be limited by effecting such appeal on sealed papers. ${ }^{123}$

\section{CoNCLUSION}

Although the question here dealt with is a rather narrow one, it touches upon fundamental principles of due process. Some recent decisions reflect a disturbing willingness to whittle down, on the ground that inferior interests are at stake, recognized procedural safeguards in adjudicative proceedings before governmental agencies that are charged with the task of seeing that justice is done. No guides appear in the decisions indicating where an interest acquires a procedurally protected status. On the contrary, in the Greene case, now pending before the Supreme Court (in which the court of appeals held that, on the basis of undisclosed information, a governmental order may require the discharge of an individual employed by a private company holding a Defense Department contract), the door has been opened to unchecked administrative intervention in the employment status of persons employed in at least 20,000 plants that have military contracts. ${ }^{124}$ The court there simply said that what is good for public employment is good for private employment. This kind of loose analogy has obvious dangers, especially where the example itself has shaky foundations.

One infers from these cases that there is, or should be, a hierarchy of interests to which different degrees of a right to procedural due process can be attached. But this is retrogressive. It has been shown in other areas that judicial gradations assigning one degree of legal protection to so-called "privileges", "benefits" or "gratuities" and another to "rights," led to inconsistent and unfair results which legislation must correct. ${ }^{125}$ Similarly, by creating overly-refined distinctions among various "rights" or "interests" deep inroads are made into fundamental procedural principles.

If "reasonable" limitations are appropriate where procedural due process is concerned, there is a sounder basis on which they can be applied. This can be, and has been, accomplished by defining, on the basis of an adjustment of the interrelated interests, the kinds of information that are presumptively privileged. The presumption, when

123. See Appeal of SEC, 226 F.2d 501 (6th Cir. 1955).

124. Greene v. McElroy, 254 F.2d 944 (D.C. Cir. 1958), cert. granted, 27 U.S.L. WEEK 3134 (U.S. Oct. 27, 1958) (No. 180).

125. See H.R. 272, 85th Cong., 1st Sess. (1957), which is a bill providing for the judicial review of determinations of the Administrator of Veterans Affairs. At the present time such determinations are non-reviewable mainly on the theory that they deal with "benefits" or "gratuities." See CoMmissIon ON ORGanization OF THE Executive Branch of the Government, Task Force Report on Legal Services and PrOCEDURE 208 (1955). 
formally claimed, sets in motion procedural machinery whereby the ultimate decision on the right to withhold information is in the hands of the court. At the same time, protection against undue disclosure of the information is provided by the limited exposure of in camera proceedings. This, of course, is the import of our discussion.

This Article has also reviewed the rationale underlying the types of information presumptively privileged at common law, and elaborated on them to some extent on the basis of recent experience. If this classification is valid, it may be desirable to incorporate it in legislation, and also to eliminate such existing provisions as might cause confusion.

Thus, there would be no need to retain the present provisions of the Federal Administrative Procedure Act which state that information may be withheld concerning "any function of the United States requiring secrecy in the public interest," ${ }^{126}$ or "required for good cause to be held confidential." 127 The proposed "Code of Federal Administrative Procedure" of the ABA, presently under discussion as a replacement for the Administrative Procedure Act, recognizes this. It names four categories of subject matter which an agency will not be required to disclose: "subject matter which is (1) specifically exempt from publication by statute, (2) required to be kept secret in the protection of national security, (3) submitted in confidence pursuant to statute or agency rule or direction, or (4) the disclosure of which would be a clearly unwarranted invasion of personal privacy."

Although this is a decided improvement over the Administrative Procedure Act, it falls somewhat short of the standards which the analysis here advanced discloses. Item (3) of the proposal, information "submitted in confidence pursuant to statute or agency rule or direction," is too vague. Almost any information submitted to an agency can be brought within its terms. This provision should be deleted and a category of "communications relating to internal management" be added. Furthermore, the bill fails to provide for information relating to international relations, generally recognized under the common law "secrets of state" privilege, and the informer privilege. In addition, since the Federal "Housekeeping" Act has been amended to preclude its use as a basis for regulations dealing with the nondisclosure of information by subordinate officials, ${ }^{128}$ another provision should be added to such a bill, authorizing the issuance of regulations governing disclosure of information by subordinate agency officials. This would preserve the rule of the Boske and Touhy cases. ${ }^{129}$

126. 60 Stat. 238 (1946), 5 U.S.C. $\$ 1002(1)$ (1952)

127. 60 Stat. 238 (1946), 5 U.S.C. $\$ 1002$ (2) (b) (1952).

128. See notes 23,24 sispra.

129. See notes 21,22 supra. 
Finally, we might note that the full implications of the Jencks and Reynolds cases still remain to be developed. Does Jencks stand for the proposition that no privilege will be recognized in a criminal prosecution? If not, which of the privileged types of information will be recognized? It will be recalled that Mr. Justice Brennan indicated that in civil causes "the protection of vital national interests [secrets of state?] may militate against public disclosure of documents in the Government's possession." And, he went on to say, quoting from Mr. Chief Justice Vinson's opinion in the Reynolds case, that in criminal causes

"the Government can invoke its evidentiary privileges only at the price of letting the defendant go free. The rationale of the criminal cases is that, since the Government which prosecutes an accused also has the duty to see that justice is done, it is unconscionable to allow it to undertake prosecution and then invoke its governmental privileges to deprive the accused of anything which might be material to his defense . . . ." 130

Does this apply to information admittedly "secrets of state"? To the names of informers?

In Reynolds, where it is assumed that the full panoply of privileged types of information would apply in civil cases, the Court did not reach the issue of privilege, or the manner in which it is to be determined. It interpolated a requirement of a showing of "necessity" when the government claimed privilege and there was a "reasonable possibility" that it would be upheld. Since the case concerned a discovery proceeding under rule 34 of the Federal Rules of Civil Procedure, a requirement of a showing of necessity would be technically justified if it could be equated with the showing of "good cause" which rule 34 requires as a basis for the issuance by the court of an order to compel production of requested documents. If this is so, the showing of "necessity" would not be required where the information is sought for use at trial pursuant to subpoena under rule 45 , since the latter rule does not provide for a showing of good cause.

Where these technical hurdles are surmounted, it appears, as indicated in the recent case of Mitchell $v$. Bass, ${ }^{131}$ that the federal courts will insist that they have the final say as to whether particular matters are privileged, and further thought must now be given to the mechanics of preventing unnecessary disclosure of allegedly privileged information in the process of such determination. 